\title{
Perlindungan Hukum Bagi Pemilik Karya Cipta Batik Tulis Dewi Rengganis Di Desa Jatiurip Kecamatan Krejengan Kabupaten Probolinggo
}

\author{
Nuzulia Kumala Sari ${ }^{1}$ \\ Dyah Ochtorina Susanti ${ }^{2}$ \\ ${ }^{1}$ Fakultas Hukum Universitas Jember, Jember, Indonesia \\ E-mail:nuzuliaks@gmail.com \\ ${ }^{2}$ Fakultas Hukum Universitas Jember, Jember, Indonesia \\ E-mail:dyahochtorina.fh@unej.ac.id
}

\begin{abstract}
This research background by the existence of Dewi Rengganis Batik which is the characteristic of Jatiurip Village, Krejengan District, Probolinggo Regency, where each batik motif tells about the figure of Dewi Rengganis who is the daughter of Prabu Brawijaya from the Majapahit Kingdom, but the batik has not been registered. This resulted in the owner of Batik Dewi Rengganis not getting legal protection. The results of this study using normative Legal Research with statute approach and conceptual approach are to provide an explanation and understanding of the importance of copyright registration to protect the copyrighted works of Batik Dewi Rengganis, and describe legal protection for owners of Batik Dewi Rengganis works in Jatiurip Village, Krejengan District Probolinggo Regency.
\end{abstract}

Keywords: Legal Protection, Copyright, Batik Dewi Rengganis.

\section{A. PENDAHULUAN.}

Desa Jatiurip merupakan salah satu Desa yang terletak di Kecamatan Krejengan, Kabupaten Probolinggo., dimana kecamatan krejengan sendiri berada di sebelah tenggara dengan batas-batas Utara yakni Kecamatan Kraksaan, Timur yakni Kecamatan Besuki, Selatan yang merupakan Kecamatan Gading, dan arah Barat berbatasan dengan Kecamatan
Pajarakan. ${ }^{1}$ Berkaitan dengan hal tersebut, Wilayah Kabupaten Probolinggo yang dikelilingi oleh gunung-gunung yang membujur dari barat ke timur, yakni Gunung Semeru, Gunung Argopuro, Gunung Tengger dan Gunung Lamongan menyebabkan tanah yang ada di Kabupaten Probolinggo, termasuk di Desa Jatiurip mengandung mineral yang berasal dari ledakan gunung berapi

${ }^{1}$ http://www.probolinggo.org / index.php / beranda / probolinggo - kabupaten/krejengan, (Diakses pada tanggal 5 Desember 2018). 
berupa pasir dan batu, lumpur bercampur dengan tanah liat yang berwarna kelabu kekuning-kuningan. Sifat tanah semacam ini mempunyai tingkat kesuburan tinggi dan sangat cocok untuk jenis tanaman sayur-sayuran dan tanaman lainnya, sehingga mengacu pada potensi tersebut, mayoritas masyarakat Jatiurip dimana bermata pencaharian sebagai Petani dengan memanfaatkan lahan pertanian yang luas dan subur untuk memperbaiki perekonomiannya.

Berkaitan dengan hal tersebut, selain potensi di bidang pertanian, Desa Jatiurip juga memiliki potensi besar di bidang Kerajinan dan ketrampilan. Hal ini dibuktikan dengan adanya beberapa usaha di bidang kerajinan dan ketrampilan di Desa Jatiurip, dan salah satu yang paling dikenal yaitu Batik Tulis Dewi Rengganis.

Batik Tulis Dewi Rengganis merupakan salah satu dari tiga pioner pengrajin batik tulis di Kabupaten Probolinggo, Jawa Timur. Hasil batiknya dari segi kualitas dan kuantitas memang tidak perlu diragukan lagi, bahkan, konsistensi dan eksistensinya dalam menginspirasi sesama insan batik di Kabupaten Probolinggo dalam berkarya itu masih terjaga hingga saat ini.

Batik Dewi Rengganis sendiri memiliki ciri khas serta keunikan motif yang berbeda dengan motif-motif batik lainnya, dimana disetiap motif batik tersebut menceritakan sosok sang Dewi Rengganis yang digambarkan sebagai seorang perempuan yang sangat cantik jelita dan merupakan salah seorang putri dari Prabu Brawijaya, Raja Majapahit, yang menurut cerita rakyat setempat, sang putiri pernah tinggal di antara Kecamatan Krucil, Tiris dan Krejengan. Dewi Rengganis sendiri. ${ }^{2}$ Terkait demikian, untuk lebih jelasnya, berikut contoh motif Batik Dewi Rengganis:

2 Hasil Wawancara Tim Pengabdian Nuzulia Kumala Sari dan Dyah Ochtorina Susanti, pada bulan Desember 2018.
Gambar 1.

Batik Dewi Rengganis
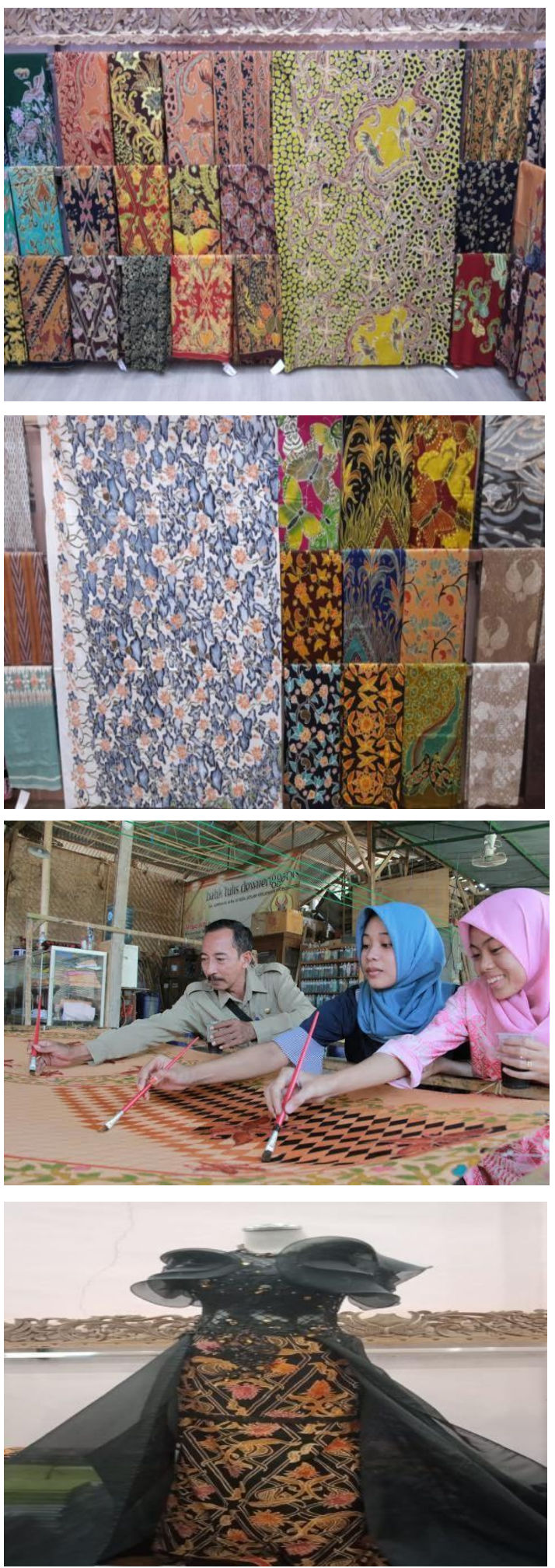

Berdasarkan penjelasan sebagaimana yang telah diuraikan di atas, perlu diketahui pula bahwa untuk membuat dan menghasilkan motif Batik 
Dewi Rengganis tidaklah mudah, diperlukan suatu keterampilan dan kreatifitas yang tentu membutuhkan waktu lama, bahkan hingga mengorbankan waktu, tenaga, dan pikiran. Hal itu dikarenakan motif Dewi Rengganis merupakan perwujudan karya intelektual manusia, maka wajar jika Batik Dewi Rengganis harulah dilindungi agar pihak-pihak lain tidak menggunakannya untuk kepentingan komersial tanpa izin dari pencipta karya tersebut. Latar belakang yang sudah dijelaskan diatas maka terdapat topik menarik yang perlu dibahas dan menjadi tema sentral dalam artikel ini yaitu apa bentuk perlindungan hukum bagi pemilik karya cipta motif batik tulis Dewi Rengganis?

\section{B. METODE PENELITIAN}

Jenis penelitian dalam karya ilmiah ini yakni penelitian hukum normatif atau penelitian doktrinal, yang dilakukan dengan mengkaji berbagai aturan hukum yang bersifat formil seperti undang-undang dan peraturan-peraturan lain yang kemudian dihubungkan dengan permasalahan yang akan dibahas dalam penelitian ini. Soejono dan Abdurrahman dalam Dyah Ochtorina Susanti mengemukakan bahwa penelitian normatif atau doktrinal adalah penelitian yang objek kajiannya adalah dokumen peraturan perundang-undangan dan bahan pustaka. ${ }^{3}$ Berdasarkan hal tersebut, maka objek kajian di dalam karya ilmiah ini yaitu berbagai peraturan perundang-undangan yang berkaitan dengan peraturan-peraturan dan bahan pustaka yang memuat perlindungan hukum hak cipta Batik Dewi Rengganis. Peraturan dan bahan pustaka tersebut Hal ini dilakukan digunakan agar

3 Soejono dan Abdurrahman. (2003). Metode Penelitian Hukum. (Jakarta: Rineka Cipta,), h. 56. Dalam Susanti, Dyah Ochtorina dan A'an Efendi. (2014). Penelitian Hukum (Legal Research). Jakarta: Sinar Grafika, h. 110. peneliti dapat menentukan bentuk pengaturan perlindungan hukum terhadap pemilik motif Batik Dewi Rengganis yang ada di Desa Jatiurip, Kecamatan Krejengan, dan Kabupaten Probolinggo.

\section{PEMBAHASAN}

Perlindungan hukum bagi suatu produk hasil karya intelektual sangatlah penting dan diperlukan, sebab karya intelektual dihasilkan oleh manusia tidak secara instan, akan tetapi memerlukan pengorbanan tenaga, waktu, dan biaya. Adanya pengorbanan tersebut menjadikan karya intelektual yang dihasilkan memiliki kualitas yang baik dan bernilai ekonomis, sehingga dapat dinikmati manfaatmya. Berdasarkan konsep tersebut, sebagai bentuk penghargaan atas hasil karya yang telah dihasilkan, maka dibentuklah perlindungan hukum bagi hak kekayaan intelektual tersebut, dengan tujuan untuk memajukan perkembangan kemajuan ilmu pengetahuan, seni dan sastra serta sebagai motivasi pencipta, pendesain, dan penemu agar lebih inovatif lagi dalam menghasilkan sebuah karya intelektual, salah satunya karya dalam bentuk seni membatik. ${ }^{4}$

Sehubungan dengan penjelasan di atas, perlunya perlindungan hukum terhadap pencipta, pendesain, atau penemu karya intelektual, juga didasarkan pada 5 (lima) teori yang dikemukakan oleh Robert M. Sherwood, yaitu pertama, Reward Theory, yang memiliki makna berupa pengakuan terhadap karya intelektual yang telah dihasilkan oleh seseorang sehingga kepada penemu/pencipta atau pendesain harus diberikan penghargaan sebagai imbalan atas upaya-upaya kreatif dalam 
menemukan/menciptakan karya-karya intelektualnya. 5 Terkait demikian, Mieke Komar dan Ahmad M. Ramli menjelaskan bahwa sebagai suatu hak yang berasal dari kemampuan intelektual manusia, maka Hak Kekayaan Intelektual (selanjutnya disingkat HKI) perlu mendapat perlindungan hukum yang memadai, sebagai imbalan atas jerih payah penemu/pencipta/pendesain suatu karya intelektual.

Teori yang kedua, yakni Recovery Theory. Teori ini berprinsip bahwa penemu/pencipta/pendesain yang telah mengeluarkan waktu, biaya serta tenaga dalam menghasilkan karya intelektualnya harus memperoleh kembali apa yang telah dikeluarkannya tersebut. 6 Pengeluaran-pengeluaran tersebut sebagai wujud konkret dari pengorbanan yang telah diberikan seseorang atau badan hukum dalam menghasilkan karya intelektual yang bermanfaat untuk masyarakat. Berdasar demikian, pemerintah harus membentuk hukum HKI yang berlandaskan asas keadilan dengan mengembalikan keseluruhan pengeluaran sebagai bentuk perbaikan terhadap pengorbanan berupa pemikiran, tenaga, waktu, biaya, bahkan perasaan tersebut. ${ }^{7}$

Teori selanjutnya yakni Incentive Theory, teori yang menjelaskan adanya keterkaitan antara pengembangan kreatifitas dengan memberikan insentif bagi para penemu/pencipta/pendesain tersebut. Artinya, insentif perlu diberikan untuk mengupayakan terpacunya kegiatan-kegiatan penelitian yang

5 Sherwood, Robert M. (1990). Intellectual Property and Economic Development: Westview Special Studies in Science,Technology and Public Agency. SanFransisco: Westview Press Inc, h. 37

6 Ibid.

7 Syaifuddin, Muhammad dan Handayani, Sri (2017). Hukum Perlindungan Rekayasa Genetika : Relasi Moral, Hak Kekayaan Intelektual, dan Pelindungan Varietas Tanaman dan Paten di Indonesia. Malang: Setara Press, h. 146. berguna $^{8}$, atau dengan kata lain bahwa negara dan/atau pihak lain (bukan negara) memberikan insentif agar orang atau badan hukum akan termotivasi, sehingga berupaya untuk terus menghasilkan karya intelektual yang lebih kreatif dan inovatif. Terkait bentuk konkrit dari penerapan Incentive Theory, yaitu ditetapkannya royalti sebagai hak dari penemu / pemilik / pendesain. Pemberian royalty diharapkan dapat memacu semangat kepada penemu / pencipta / pendesain untuk mengembangkan dan menciptakan inovasi- inovasi baru yang lebih baik dan berguna bagi masyarakat. ${ }^{9}$

Teori yang keempat yaitu Risk Theory, teori yang menyatakan bahwa suatu karya mengandung resiko. Resiko yang dapat memungkinkan orang lain yang terlebih dahulu menemukan cara atau memperbaikinya, ${ }^{10}$ misalnya adanya resiko yang mungkin timbul dari penggunaan secara ilegal karya tersebut. Hal lainnya yakni resiko berupa pemanfaatan HKI tanpa izin atau persetujuan dari pemilik atau pemegang HKI yang terdaftar jika hal itu menimbulkan kerugian secara ekonomis maupun moral bagi penemu / pencipta / pendesain, sehingga perlu diberikan suatu bentuk pelindungan hukum terhadap upaya atau kegiatan yang mengandung resiko tersebut. ${ }^{11}$ Teori yang terakhr yakni Economic Growth Stimulus Theory, teori yang mengakui bahwa perlindungan atas HKI adalah merupakan suatu alat dari pembangunan ekonomi, berupa keseluruhan tujuan dibangunnya suatu sistem perlindungan atas HKI yang efektif.

Berdasarkan kelima teori di atas, maka dapat dilihat bahwa perlindungan hukum terkait HKI bagi penemu/pemilik/pencipta atas karya

8 Sherwood, Robert M. Op. Cit., h. 39.

9 Syaifuddin, Muhammad dan Handayani, Sri. Op. Cit., h. 146.

10 Sherwood, Robert M. Op. Cit., h. 39.

11 Ibid. 
intelektual yang telah dihasilkan, dilakukan agar penemu/pemilik/pencipta mendapatkan hak-haknya baik itu hak berupa moral, materi, dan hak-hak lainnya. Perlindungan juga diberikan sebagai bentuk penghargaan atas kerja keras, pengorbanan waktu, tenaga, dan biaya untuk menghasilkan karya intelektual dan inovatif tersebut.

Sehubungan dengan makna perlindungan hukum sendiri, kata "perlindungan" menurut Kamus Bahasa Indonesia diartikan sebagai tempat berlindung, hal (perbuatan, dan sebagainya) melindungi. ${ }^{12}$ Pada tataran umum, perlindungan berarti mengayomi sesuatu dari hal-hal yang berbahaya, sesuatu tersebut bisa berupa kepentingan, benda atau pun barang. Perlindungan juga mengandung arti pengayoman yang diberikan oleh seseorang terhadap orang yang lebih lemah. ${ }^{13}$

Berkenaan dengan kata hukum, menurut Hans Kelsen dalam Jimly Asshidiqie dan Ali Safa'at, berperndapat bahwa hukum adalah tata aturan (rule) sebagai suatu sistem aturan-aturan (rules) tentang perilaku manusia. Berdasar demikian, hukum tidak menumpuk pada satu aturan tunggal (rule) tetapi separangkat aturan (rules) yeng memiliki satu kesatuan sehingga dapat dipahami sebagai suatu sistem, konsekuensinya adalah tidak mungkin memahami hukum jika hanya memperhatikan satu aturan saja. ${ }^{14}$ Sudikno Mertokusumo, juga memberikan pengertian hukum yakni sebagai kumpulan peraturan - peraturan atau kaidah-kaidah dalam suatu kehidupan bersama, keseluruhan peraturan tentang tingkah laku yang berlaku dalam kehidupan bersama, yang

12 Tim Redaksi Kamus Bahasa Indonesia. (2008). Kamus Bahasa Indonesia. Jakarta: Pusat Bahasa Departemen Pendidikan Nasional, h. 864.

13 http://erepo.unud.ac.id / 9833 / 3 / 0be0ef7 d5a 3081532e17e5236d8ff561. pdf, (Diakses pada tanggal 07 Mei 2018).

14 Asshidiqie, Jimly dan Safa'at, Ali. (2006). Teori Hans Kelsen tentang Hukum. Jakarta: Sekjen dan Kepaniteraan MK-RI, h.13. dapat dipaksakan pelaksaannya dengan suatu sanksi. ${ }^{15}$ Berdasarkan pengertian hukum tersebut, maka tujuan dari hukum sendiri yakni agar tercapai suatu ketertiban dalam masyarakat sehingga diharapkan kepentingan manusia akan terlindungi untuk mencapai tujuannya dan bertugas membagi hak dan kewajiban antar perorangan dalam masyarakat, membagi wewenang dan mengutamakan pemecahan masalah hukum serta memelihara kepastian hukum. ${ }^{16}$ Hukum juga dibuat untuk melindungi kepentingan seseorang dengan cara mengalokasikan suatu kekuasaan kepadanya secara terukur, dalam arti ditentukan keluasan dan kedalamannya, untuk bertindak dalam rangka kepentingannya, yang disebut sebagai hak. ${ }^{17}$

Definisi hak dikemukakakan oleh Soeroso yaitu kewenangan atau kekuasaan yang diberikan oleh hukum kepada subyek hukum. ${ }^{18}$ Hal ini menunjukkan bahwa hanya kekuasaan tertentu saja yang dapat disebut sebagai hak. Terkait demikian, menurut hukum, terdapat 5 (lima) ciri-ciri hak yaitu: ${ }^{19}$ (1) Melekat pada seseorang yang disebut sebagai pemilik atau subjek dari hak itu; (2) Tertuju kepada orang lain, yaitu yang menjadi pemegang kewajiban, dimana antara hak dan kewajiban memiliki keterkaitan yang sangat erat. (3) Ada pada seseorang mewajibkan pihak lain untuk melakukan (commission) atau

15 Syahputra, Erwin. (2017). Pengentasan Kemiskinan Melalui Hukum Sebagai Sarana Pemberdayaan CSR (Corporate Social Responsibility) Dalam Kegiatan Pertambangan Emas Di Tapanuli Selatan. Tesis, Universitas Diponegoro, h. 59.

16 http://erepo.unud.ac.id / 9833 / 3 / 0be0e f7d5a 3081532e 17e5236d8ff561. pdf, (Diakses pada tanggal 7 Februari 2018).

17 Ibid.

18 Soeroso. (2013). Pengantar lImu Hukum. Jakarta: Sinar Grafika, h. 269.

19 Susanti, Dyah Ochtorina. 2011. Bahan Ajar Mata Kuliah Teori Hukum, disampaikan di Program Pasca Sarjana Ilmu Hukum Universitas Islam Kadiri (UNISKA). h. 2. 
tidak melakukan (omission) sesuatu perbuatan; (4) Commission atau omission sebagaimana yang dimaksud pada point 3 menyangkut sesuatu yang bisa disebut sebagai objek dari hak; (5) mempunyai titel, yaitu suatu peristiwa tertentu yang menjadi alasan melekatnya hak itu kepada pemiliknya.

Berdasarkan penjelasan di atas, maka definisi perlindungan hukum menurut Satjipto Raharjo adalah suatu tindakan memberikan perlindungan atau pengayoman kepada hak asasi manusia yang dirugikan orang lain, dimana perlindungan tersebut diberikan kepada masyarakat agar masyarakat dapat menikmati semua hak-hak yang diberikan oleh hukum. ${ }^{20}$ Berkaitan dengan pendapat Satjipto, Setiono juga mengemukakan bahwa perlindungan hukum merupakan tindakan atau upaya untuk melindungi masyarakat dari perbuatan sewenang-wenang penguasa yang tidak sesuai dengan aturan hukum, serta mewujudkan ketertiban dan ketentraman sehingga manusia dapat menikmati hak-hak yang dimilikinya. ${ }^{21}$

Di Indonesia sendiri, perlindungan hukum yang banyak digunakan yakni perlindungan hukum Salmond yang dikembangkan oleh Philipus M. Hadjon, yang enurut pendapatnya dalam Dyah Ochtorina Susanti, perlindungan hukum dibagi menjadi 2 (dua) bentuk, yakni perlindungan hukum preventif dan perlindungan hukum represif. ${ }^{22}$ Bentuk perlindungan hukum yang pertama yakni perlindungan hukum preventif merupakan perlindungan yang bertujuan untuk mencegah terjadinya sengketa, dalam hal ini rakyat dapat mengajukan keberatan (inspraak) atau pendapatnya sebelum ditetapkannya keputusan pemerintah, dimana pada saat

\footnotetext{
${ }^{20}$ Rahardjo., Satjipto. (2000). Ilmu hukum. Bandung: Citra Aditya Bakti, h. 53

21 Setiono. (2004). Rule of Law (Supremasi Hukum). Surakarta: Program Pascasarjana Universitas Sebelas Maret, , h. 3.

${ }^{22}$ Susanti, Dyah Ochtorina Op. Cit., h.2
}

pengambilan keputusan, pemerintah harus berdasarkan diskresi dan bersikap hati- hati. ${ }^{23} \mathrm{Hal}$ ini berbeda dengan bentuk perlindungan hukum kedua yakni represif, yang bertujuan untuk menyelesaikan terjadinya sengketa, baik secara litigasi maupun non litigasi sebagai upaya perlindungan hukum bagi rakyat. ${ }^{24}$

Berdasarkan pengertian kedua bentuk perlindungan hukum di atas, pengaturan perlindungan hukum terhadap hasil karya intelektual termasuk pada bentuk perlindungan preventif. Pengaturan sebagaimana yang dimaksud dibuat dengan tujuan untuk mencegah terjadinya permasalahan-permasalahan yang timbul terkait dengan pelanggaran hak karya-karya intelektual manusia, salah satu pengaturan tersebut yakni Hak Cipta yang diatur di dalam Undang-undang Nomor 28 Tahun 2014 tentang Hak Cipta (selanjutnya disebut UU Hak Cipta).

Definisi Hak Cipta di dalam hukum positif Indonesia telah diatur, tepatnya di dalam Pasal 1 ayat 1 UU Hak Cipta yang isinya sebagai berikut:

"Hak Cipta adalah hak eksklusif pencipta yang timbul secara otomatis berdasarkan prinsip deklaratif setelah suatu ciptaan diwujudkan dalam bentuk nyata tanpa mengurangi pembatasan sesuai dengan ketentuan peraturan perundang-undangan".

Pengertian lain Hak Cipta adalah hak yang mengatur karya intelektual di bidang ilmu pengetahuan, seni dan sastra yang dituangkan dalam bentuk yang khas dan telah dituangkan dalam wujud tetap, atau dengan kalimat lain. ${ }^{25} \mathrm{Hak}$ Cipta juga diartikan lain yaitu hak

\footnotetext{
23 Ibid.

24 Ibid.

25 Mujiyono. 2017). Buku Panduan Permohonan Hak Kekayaan Intelektual (Hak Cipta). Yogyakarta: Sentra HKI LPPM Universitas Negeri Yogyakarta, h. 1.
} 
eksklusif bagi pencipta atau penerima hak untuk mengumumkan atau memperbanyak ciptaannya atau memberikan izin untuk itu dengan tidak mengurangi pembatasan-pembatasan menurut peraturan perundang- undangan yang berlaku. ${ }^{26}$

Berkaitan dengan definisi-definisi hak cipta di atas, dapat ditemukan 3 (tiga) unsur yang terdapat di dalam definisi hak cipta, yakni hak eksklusif, pencipta, dan ciptaan. Hak eksklusif sebagaimana yang dimaksud diartikan bahwa tidak ada orang lain yang boleh menggunakan, memanfaatkan, dan melakukan hak itu hak tersebut tanpa izin pencipta. Hal ini dimaksudkan sebagai bentuk penghargaan dari hasil jerih payah dalam mengorbankan akal, tenaga, pikiran, dan waktu pencipta tersebut. ${ }^{27}$ Terkait pengertian Pencipta yakni seorang atau beberapa orang yang secara sendirisendiri atau bersama-sama menghasilkan suatu ciptaan yang bersifat khas dan pribadi. ${ }^{28}$ Ciptaan sebagaimana yang dimaksud yaitu setiap hasil karya cipta di bidang ilmu pengetahuan, seni, dan sastra yang dihasilkan atas inspirasi, kemampuan, pikiran, imajinasi, kecekatan, keterampilan, atau keahlian yang diekspresikan dalam bentuk nyata. ${ }^{29}$ Hal ini dengan kata lain bahwa suatu ciptaan tidak boleh hanya berupa khayalan semata tanpa ada bukti konkrit, dan dapat dilihat, dirasakan, atau diraba oleh manusia. Terkait demikian, perlu diketahui dan dipahai pula bahwa tidak semua karya-karya intelektual yang diciptakan oleh pencipta dapat dilindungi dan berlaku UU Hak Cipta.

26 Hariyani, Iswi. (2010). Prosedur Mengurus HAKI (Hak Atas Kekayaan Intelektual) yang Benar. Yogyakarta: Penerbit Pustaka Yustisia, h. 44.

27 Sitorus, Ade Uswatun. (2015). Hak Cipta dan Perpustakaan. Jurnal Iqra' Vol. 09 No.02, Oktober, h. 253.

${ }^{28}$ Lihat Pasal 1 angka 2 Undang-Undang Nomor 28 Tahun 2014 tentang Hak Cipta

29 Lihat Pasal 1 angka 3 Undang-Undang Nomor 28 Tahun 2014 tentang Hak Cipta
Berkenaan dengan hal tersebut, UU Hak Cipta telah mengatur ruang lingkup atau jenis-jenis hasil karya yang dapat memperoleh perlindungan yang tercantum di dalam Pasal 40 ayat (1) UU Hak Cipta yang membaginya menjadi 3 bidang yakni bidang ilmu pengetahuan, seni, dan sastra, dan bidang-bidang tersebut meliputi karya-karya sebagai berikut:

1. Bidang Ilmu Pengetahun, terdiri dari:

a. Alat peraga yang dibuat untuk kepentingan pendidikan dan ilmu pengetahuan;

b. Peta;

c. Kompilasi Ciptaan atau data, baik dalam format yangdapat dibaca dengan Program Komputer maupun media lainnya;

d. Program Komputer.

2. Bidang Seni

a. Terjemahan, tafsir, saduran, bunga rampai, basis data, adaptasi, aransemen, modifikasi;

b. Buku, pamflet, karya tulis yang diterbitkan, dan semua hasil karya tulis lainnya;

e. Ceramah, kuliah, pidato, dan Ciptaan sejenis lainnya.

3. Bidang Sastra

a. Lagu dan/atau musik dengan atau tanpa teks;

b. Film, drama musikal, tari, koreografi, pewayangan, dan pantomim;

c. Karya seni rupa dalam segala bentuk seperti lukisan,gambar, ukiran, kaligrafi, seni pahat, patung, atau kolase;

d. Karya seni terapan;

e. Karya arsitektur;

f. Karya seni batik atau seni motif lain;

g. Karya fotografi;

h. Potret;

i. Karya sinematografi; 
j. Terjemahan, aransemen, transformasi, atau modihkasi ekspresi budaya tradisional;

k. Kompilasi budaya tradisional selama kompilasi tersebut merupakan karya yang asli;

1. Video.

Ruang lingkup karya cipta yang dapat dilindungi sebagaimana yang disebut di atas menunjukkan bahwa terdapat batasan-batasan terhadap hasil karya intelektual, karena tidak semua ciptaan seseorang mendapatkan perlindungan hak cipta. Berdasarkan jenis-jenis karya cipta di atas, maka motif batik tulis Dewi Rengganis hasil karya intelektual pencipta yang dihasilkan oleh warga Desa Jatiurip masuk ke dalam kategori karya cipta yang dilindungi dan mendapatkan perlindungan hukum hak cipta yang di atur di dalam UU Hak Cipta.

Batik Dewi Rengganis sendiri merupakan usaha seorang warga bernama Rosyami warga RT 03/RW 03, Dusun Kuripan, Desa Jatiurip Kecamatan Krejengan, dibantu beberapa pekerja yang juga merupakan warga Desa dari dusun yang sama. Batik Dewi Rengganis tersebut merupakan produk asli Desa Jatiurip yang memiliki ciri khas tersendiri dari motif-motif batik lainnya, dimana motif batik Dewi Rengganis tersebut diambil dari cerita kerajaan Majapahit pada masa pemerintahan Prabu Brawijaya, yang mengulik kisah perjalanan kerajaan tersebut pada setiap motifnya sehingga maknanya pun berbeda-beda. Terkait demikian, untuk lebih jelasnya, berikut beberapa gambar Batik Dewi Rengganis beserta makna yang terkadung di dalam motif tersebut.
Gambar 2.

Motif Putri Kalibuntu

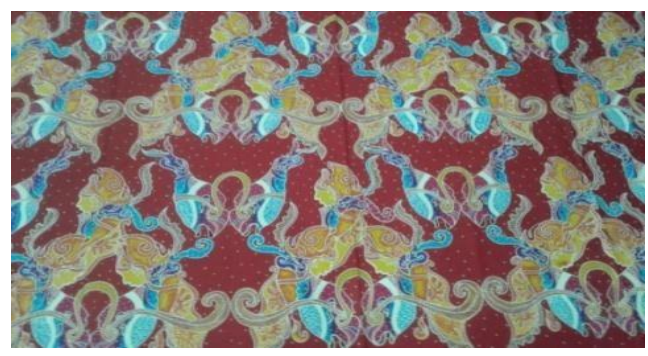

Motif Putri Kalibuntu menceritakan tentang Desa Kalibuntu yang rakyatnya hidup sebagai nelayan. Desa Kalibuntu juga terkenal dengan pesona kecantikan perempuan perempuan desanya, sehingga batik Kalibuntu digambarkan dengan motif ikan berbentuk putri.

Gambar 3.

Motif Rengganis Kasmaran

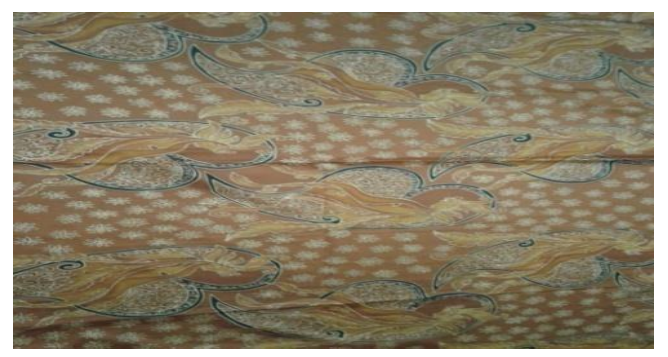

Motif Rengganis Kasmaran menceritakan tentang Dewi Rengganis yang sedang jatuh cinta, sehingga digambarkan dengan bentuk hati diibaratkan panah yang menusuk jantung sang dewi, ada pula gambar sang dewi melayang seolah-olah terlena oleh panah cinta tersebut.

Gambar 4.

Motif Panji Laras

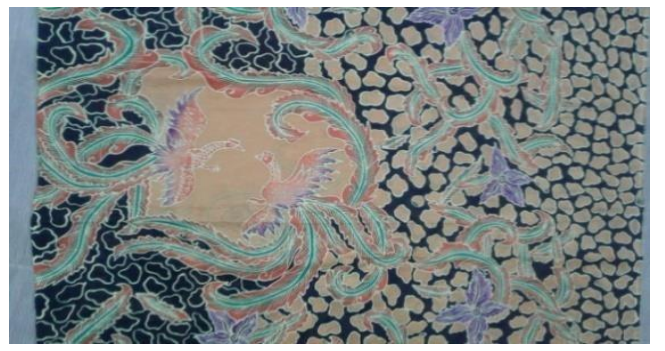

Motif Panji Laras menceritakan tentang seorang Pangeran yang senang 
mengadu ayam, sehingga digambarkan dengan sepasang ayam yang sedang bertarung.

\section{Gambar 5.}

Motif Mendem Tresno

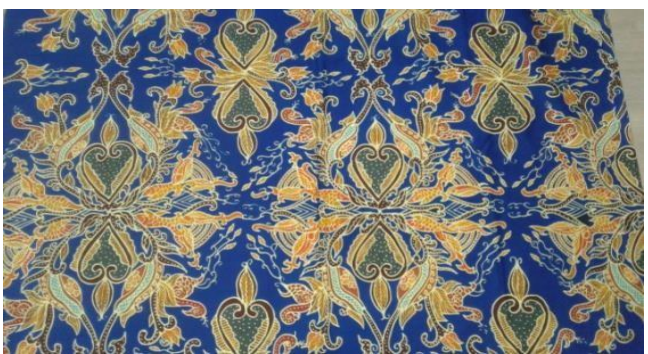

Motif

\begin{abstract}
Mendem
\end{abstract} menceritakan bawang merah

Tresno

khas dan disukai banyak orang, sehingga digambarkan dalam bentuk bawang merah probolinggo yang di tengah-tengahnya terdapat gambar cinta yang memperlihatkan kecintaan masyarakat pada bawang merah Probolinggo.

\section{Gambar 6.}

Motif Pengasihan Dewi Rengganis

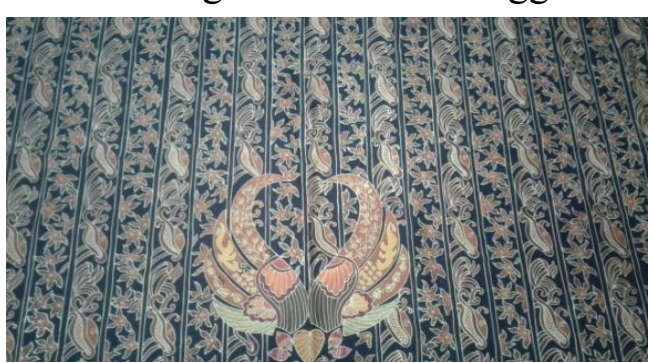

Motif Pengasihan Dewi Rengganis menceritakan sifat penyayang Dewi Rengganis yang digambarkan bentuk mahkota sang dewi, dimana warna biru sebagai warna background atau latar menandakan dalamnya kasih Dewi Rengganis. Selanjutnya ada pula gambar daun dan sulur menandakan sebuah kekuatan yang akan menyatu dalam sebuah kasih saying.

Motif-motif batik tulis Dewi Rengganis di atas dibuat tidak dengan cara yang instan, namun diperlukan keterampilan khusus untuk membuatnya, apalagi motif batik Dewi Rengganis

memiliki ciri khas yang tidak dimiliki oleh batik-batik lain. Hal inilah yang kemudian menjadi alasan banyaknya peminat motif Batik Dewi Rengganis yang tidak hanya dari wilayah Kabupaten Probolinggo saja, akan tetapi sudah menjangkau hingga ke wilayah luar Kabupaten Probolinggo bahkan Jawa Timur. Banyaknya peminat Batik Dewi Rengganis ini, mengakibatkan produksi batik meningkat, bahkan Batik Dewi Rengganis dapat memproduksi 10 helai batik dalam sehari. Hal ini tentu menguntungkan tidak hanya untuk $\mathrm{Bu}$ Rosyami selaku penemu / pendesain / pencipta Batik Dewi Rengganis, akan tetapi juga menguntungkan bagi warga pengrajin - pengrajin lain yang ikut membantu dalam pembuatan Batik.

Adanya Batik Dewi Rengganis juga mengurangi pengangguran warga Desa Jatiurip, bahkan dapat meningkatkan perekonomian masyarakat Desa Jatiurip Kecamatan Krejengan, Kabupaten Probolinggo. Manfaat dan keuntungan yang diperoleh dari adanya Batik Dewi Rengganis sebagaimana yang disebutkan di atas menunjukkan bahwa batik tersebut haruslah dijaga dan dillindungi, apalagi motif Dewi Rengganis merupakan motif batik pertama kali yang ada di Indonesia dan menjadi temuan atau ciptaan baru, bahkan menjadi ciri khas dari Desa Jatiurip, Kecamatan Krejengan, Kabupaten Probolinggo.

Perlindungan sebagaimana yang dimaksud yakni berupa perlindungan hak cipta. Perlindungan hak cipta diberikan sebagai bentuk reward kepada $\mathrm{Bu}$ Rosyami atas karya ciptaannya yakni Batik Tulis Dewi Rengganis. Hak cipta sendiri merupakan hak eksklusif yang diberikan kepada pencipta atas produk ciptaannya yang terdiri dari 2 jenis hak yang di dapat pencipta yaitu pertama, hak moral dan hak ekonomi. Bekenaan dengan hak moral diartikan sebagai hak yang melekat secara abadi pada diri Pencipta itu sendiri untuk melakukan 
hal-hal diantaranya: 30

mencantumkan atau

(a) tetap

tidak

mencantumkan nama pencipta pada

salinan sehubungan dengan pemakaian

ciptaannya untuk umum; (b)

menggunakan nama alias atau nama

samara pencipta; (c) mengubah

ciptaannya sesuai dengan kepatutan

dalam masyarakat; (d) mengubah judul dan anak judul ciptaan; dan (e) mempertahankan haknya dalam hal terjadi distorsi ciptaan, mutilasi ciptaan, modifikasi ciptaan, atau hal yang bersifat merugikan kehormatan diri atau reputasi dari pencipta. Berkaitan dengan hal tersebut, hak moral tidak dapat dialihkan selama pencipta masih hidup, tetapi pelaksanaan hak tersebut dapat dialihkan dengan wasiat atau sebab lain sesuai dengan ketentuan peraturan perundang-undangan setelah pencipta meninggal dunia, dimana pengalihannya dilakukan secara tertulis. ${ }^{31}$

Sehubungan dengan penjelasan di atas, untuk melindungi hak moral tersebut, maka pencipta memiliki hak sebagai pencipta atas karya cipta batik tulis Dewi Rengganis tersebut serta informasi elektronik Hak Cipta yang meliputi informasi mengenai suatu ciptaan, yang muncul dan melekat secara elektronik yang berhubungan pengumuman ciptaan; nama pencipta, aliasnya atau nama samarannya; pencipta sebagai pemegang Hak Cipta; masa berlakunya hak cipta dan kondisi penggunaan ciptaan; nomor; serta kode informasi. $^{32}$

Kedua, hak ekonomi yakni hak eksklusif yang diperoleh pencipta atau pemegang Hak Cipta untuk mendapatkan manfaat ekonomi atas ciptaan yang dihasilkan. ${ }^{33}$ Hak ekonomi

30 Lihat Pasal 5 ayat (1) Undang-Undang Nomor 28 Tahun 2014 tentang Hak Cipta.

31 Lihat Pasal 5 ayat (2) dan (3) Undang-Undang Nomor 28 Tahun 2014 tentang Hak Cipta.

32 Lihat Pasal 7 (2) Undang-Undang Nomor 28 Tahun 2014 tentang Hak Cipta.

${ }^{33}$ Lihat Pasal 8 Undang-Undang Nomor yang diperoleh dapat digunakan oleh pencipta untuk melakukan hal-hal diantaranya: ${ }^{34}$ (a) penerbitan ciptaan; (b) penggandaan ciptaan dalam segala bentuknya; (c) penerjemahan ciptaan; (d) pengadaptasian, pengaransemenan, atau pentransformasian ciptaan; Pendistribusian ciptaan atau salinannya; (f) pertunjukan ciptaan; (g) Pengumuman ciptaan; (h) Komunikasi ciptaan; dan (i) penyewaan ciptaan.

Hal-hal tersebut dapat digunakan untuk kepentingan komersil dan mengambil keuntungan, baik melalui penjualan hasil ciptaannya, sewa, dan lain sebagainya. Sebaliknya, hak ekonomi sebagaimana yang dimaksud tidak dapat digunakan dan dimanfaatan oleh orang lain, kecuali pencipta atau pemegang hak cipta memberikan izin untuk menggunakan hasil ciptaannya. ${ }^{35}$ Terkait demikian, apabila orang lain melanggar hak ekonomi pencipta dengan melakukan penggandaan dan/atau penggunaan secara komersial produk ciptaan tanpa izin dari pencipta atau pemegang hak cipta, maka maka orang tersebut akan dikenakan sanksi.

Pada UU Hak Cipta terkait sanksi yang diberikan kepada pelanggar hak moral maupun hak ekonomi pencipta juga telah di atur. Pada hak moral, sanksi tersebut tercantum di dalam Pasal 112 UU Hak Cipta yang menjelaskan bahwa seseorang yang tanpa hak menggunakan hak moral sebagaimana yang telah disebutkan di atas untuk kepentingan komersil, dikenakan pidana berupa pidana penjara paling lama 2 (dua) tahun dan/atau pidana denda paling banyak $\mathrm{Rp}$ 300.000.000,00 (tiga ratus juta rupiah).

Berbeda dengan hak moral yang hanya terdapat satu pengaturan terkait pengenaan sanksi pidananya, Berkenaan

\footnotetext{
28 Tahun 2014 tentang Hak Cipta.

34 Lihat Pasal 9 ayat (1) Undang-Undang Nomor 28 Tahun 2014 tentang Hak Cipta.

${ }^{35}$ Lihat Pasal 9 ayat (2) Undang-Undang Nomor 28 Tahun 2014 tentang Hak Cipta.
} 
dengan hak moral di atur di dalam Pasal 113 UU Hak Cipta yang di dalamnya terbagi menjadi 4 (empat) jenis diantaranya: jenis pertama, seseorang yang tanpa hak menyewakan hasil ciptaan pencipta, maka dipidana paling lama 1 (satu) tahun dan/atau pidana denda paling banyak Rp100.000.000,00 (seratus juta rupiah). ${ }^{36} \mathrm{Kedua}$, seseorang yang tanpa hak menerjemahkan, mengadaptasikan, mengaransemen, atau mentransformasikan ciptaan, dan mempertunjukkan ciptaan untuk tujuan komersil, maka dipidana dengan pidana penjara paling lama 3 (tiga) tahun dan/atau pidana denda paling banyak $\mathrm{Rp}$ $500.000 .000,00$ (lima ratus juta rupiah). ${ }^{37}$ Ketiga, , seseorang yang tanpa hak menerbitkan, menggandakan ciptaan dalam segala bentuknya, mendistribusikan ciptaan atau salinannya, dan/atau mengumumkan ciptaan untuk tujuan komersil, maka dipidana dengan pidana penjara paling lama 4 (empat) tahun dan/atau pidana denda paling banyak Rp 1.000.000.000,00 (satu miliar rupiah). ${ }^{38}$ Keempat, setiap orang yang melakukan perbuatan sebagaimana yang disebutkan pada jenis yang ketiga dan dilakukan dalam bentuk pembajakan, maka dipidana dengan pidana penjara paling lama 10 (sepuluh) tahun dan/atau pidana denda paling banyak $\mathrm{Rp}$ 4.000.000.000,00 (empat miliar rupiah). ${ }^{39}$

Berdasarkan penjelasan yang telah diuraikan di atas, maka dapat dilihat bahwa perlindungan Hak Cipta sangatlah diperlukan agar orang lain tidak sewenang-wenang mengambil, mencuri, dan mengakui karya milik pencipta, termasuk perlindungan terhadap motif Batik Tulis Dewi Rengganis. Hal itu

36 Lihat 113 ayat (1) Undang-Undang Nomor 28 Tahun 2014 tentang Hak Cipta.

37 Lihat 113 ayat (2) Undang-Undang Nomor 28 Tahun 2014 tentang Hak Cipta.

38 Lihat 113 ayat (3) Undang-Undang Nomor 28 Tahun 2014 tentang Hak Cipta.

39 Lihat 113 ayat (4) Undang-Undang Nomor 28 Tahun 2014 tentang Hak Cipta. dikarenakan dengan adanya perlindungan hak cipta, maka $\mathrm{Bu}$ Rosyami selaku Pencipta motif batik tersebut dapat ditetapkan menjadi pemilik dan memperoleh hak cipta atas karya intelektualnya sebagaimana yang telah dijelaskan di atas.

Berkenaan dengan bentuk perlindungan represif, diimplementasikan melalui ketersediaan pilihan penyelesaian sengketa hak cipta, dimana apabila terjadi pelanggaran terhadap hak atas kekayaan intelektual pencipta, maka dapat diselesaikan melalui jalur litigasi (pengadilan) atau nonlitigasi (Alternatif Penyelesaian Sengketa atau APS, seperti negosiasi, mediasi, konsiliasi, dan lain-lain). Berkaitan dengan hal tersebut, dari kedua jenis penyelesaian sengketa di atas, penyelesaian yang banyak diminati dalam menyelesaikan sengketa HKI dan lingkungan yakni menggunakan penyelesaian melalui Alternatif Penyelesaian Sengketa (selanjutnya disingkat (APS). APS merupakan upaya hukum yang ditempuh akibat ketidakpuasan penyelesaian sengketa melalui proses litigasi yang konfrontatif dan bertele-tele. ${ }^{40}$ Terkait demikian, selain biayanya murah, penyelesaian menggunakan metode ini juga tidak memakan banyak waktu dan tenaga. Hal inilah yang kemudian menjadi alasan penyelesaian melalui jalur non litigasi ini banyak diminati oleh masyarakat.

Pengaturan terkait APS sendiri tertuang di dalam Undang-Undang Nomor 30 Tahun 1999 tentang Arbitrase dan Alternatif Penyelesaian Sengketa (selanjutnya disebut UU Arbitrase dan $A P S)$. Pengaturan APS diatur pula di dalam UU Hak Cipta, tepatnya pada Pasal 95 ayat (1) UU Hak Cipta yang

40 Kurniawaty, Yuniar.

(2017). Efektivitas Alternatif Penyelesaian Sengketa Dalam Sengketa Kekayaan Intelektual (Alternative Dispute Resolution On Intellectual Property Dispute). Jurnal Legislasi Indonesia, Vol. 14 No. 02 - Juni, h. 166. 
menjelaskan bahwa penyelesaian sengketa hak cipta dapat dilakukan melalui alternatif penyelesaian sengketa, arbitrase, atau pengadilan. Terkait pengertian APS sendiri menurut UU Hak Cipta adalah proses penyelesaian sengketa melalui mediasi, negosiasi atau konsiliasi. Berdarkan pengertian tersebut, maka terdapat 3 (tiga) bentuk APS yang dapat digunakan untuk menyelesaikan sengketa pelanggaran Hak Cipta, termasuk ciptaan motif Batik Dewi Rengganis, yakni:

1) Mediasi adalah penyelesaian penyelesaian sengketa dengan melibatkan pihak ketiga yang netral guna membantu para pihak mencapai kesepakatan. ${ }^{41}$ Mediasi juga diartikan sebagai mekanisme penyelesaian sengketa dengan bantuan pihak ketiga yang disebut Mediator. Mediator dalam hal ini tidak berwenang untuk memutus sengketa, tetapi hanya membantu para pihak untuk menyelesaikan persoalan-persoalan yang dikuasakan kepada mediator tersebut, serta memberikan bimbingan atau arahan guna mencapai penyelesaian namun tidak berfungsi sebagai hakim yang berwenang mengambil putusan. ${ }^{42}$

2) Negosiasi adalah suatu bentuk penyelesaian sengketa oleh para pihak, tanpa bantuan pihak lain, dengan cara musyawarah atau berunding untuk mencari pemecahan yang dianggap adil

41 Umam, Khotibul. (2010). Penyelesaian Sengketa di Luar Pengadilan. Yogyakarta: Pustaka Yustisia, h. 10.

42 Tim Peneliti Alternative Disputes Resolution. (2000). Laporan Penelitian Alternative Despute Resolution (Penyelesaian Sengketa Alternatif) dan Court Connected Dispute Resolution (Penyelesaian Sengketa yang Terkait dengan Pengadilan. Jakarta: Proyek Penelitian dan Pengembangan Mahkamah Agung RI, h. 16. oleh para pihak. ${ }^{43} \mathrm{Hal}$ yang dicapai dari negosiasi berupa penyelesaian kompromi.

Negosiasi juga diartikan sebagai proses yang dilakukan oleh dua pihak wakil dengan permintaan (kepentingan) yang saling berbeda dengan membuat suatu persetujuan secara kompromis dan memberikan kelonggaran demi tercapainya penyelesaian secara damai. 45 Terkait demikian, para pihak yang melakukan negosiasi disebut negosiator. Mekanisme APS dalam bentuk ini yakni para pihak yang bersengketa berhadapan langsung dalam mendiskusikan permasalahan yang dihadapi secara korporatif dan terbuka. ${ }^{46}$

3) Konsiliasi adalah penciptaan penyesuaian pendapat dan penyelesaian suatu sengketa dengan suasana persahabatan dan tanpa ada rasa permusuhan yang dilakukan di pengadilan sebelum ketiga dimulainya persidangan dengan maksud untuk menghindari proses legitasi. 47 Konsiliasi juga merupakan mekanisme penyelesaian sengketa dengan intervensi pihak ketiga. Pihak ketiga (konsiliator) mengambil inisiatif menyusun dan merumuskan langkah-langkah penyelesaian, yang selanjutnya diajukan dan ditawarkan kepada para pihak yang bersengketa. Konsiliator tidak berwenang membuat putusan, tetapi hanya berwenang membuat rekomendasi, yang pelaksanaannya sangat tergantung dari itikad baik para

${ }^{43}$ Ibid., h. 15

44 Ibid.

45 Umam, Khotibul. Op. Cit., h. 10.

46 Sodikin. (2003). Penegakan Hukum Lingkungan: Tinjauan atas Undang-Undang Nomor 23 Tahun 1997. Jakarta: Djambatan, h. 105.

47 Khotibul Umam. Loc. Cit. 
pihak yang bersengketa sendiri. ${ }^{48}$

Bentuk-bentuk APS sebagaimana yang disebutan di atas dapat digunakan oleh masyarakat, khususnya pemilik Batik Dewi Rengganis untuk menyelesaikan sengketa di bidang hak cipta atas kepemilikan motif Batik Dewi Rengganis. APS merupan jalur penyelesaian yang efektif untuk masyarakat, sebab selain biaya murah, penyelesaiannyapun juga cepat, sehingga tidak perlu menunggu terlalu lama.

\section{PE N U T U P}

Bentuk Perlindungan Hukum Bagi Pemilik Karya Cipta Motif Batik Tulis Dewi Rengganis terdiri dari 2 (dua) bentuk yaitu pertama, bentuk perlindungan preventif yang diimplementasikan dalam pembentukan Undang-Undang Nomor 28 Tahun 2014 tentang Hak Cipta (selanjutnya disebut UU Hak Cipta) sebagai pengaturan perlindungan hukum hak cipta terhadap karya intelektual motif Batik Dewi Rengganis untuk mencegah terjadinya permasalahan-permasalahan yang timbul terkait dengan pelanggaran hak atas hasil ciptaan dari pencipta. Kedua, bentuk perlindungan represif yang diimplementasikan melalui ketersediaan pilihan penyelesaian sengketa hak cipta, dimana apabila terjadi pelanggaran terhadap hasil karya cipta motif Dewi Rengganis, maka dapat diselesaikan melalui jalur litigasi (pengadilan) atau nonlitigasi (negosiasi, mediasi, dan konsiliasi).

\section{DAFTAR PUSTAKA}

Asshidiqie, Jimly dan Safa'at, Ali. (2006). Teori Hans Kelsen tentang Hukum. Jakarta: Sekjen dan Kepaniteraan MK-RI.

48 Tim Peneliti Alternative Disputes Resolution. Op. Cit., h. 16.
Hariyani, Iswi. (2010). Prosedur Mengurus HAKI (Hak Atas Kekayaan Intelektual) yang Benar. Yogyakarta: Penerbit Pustaka Yustisia.

Mujiyono. 2017). Buku Panduan Permohonan Hak Kekayaan Intelektual (Hak Cipta). Yogyakarta: Sentra HKI LPPM Universitas Negeri Yogyakarta.

Rahardjo., Satjipto. (2000). Ilmu hukum. Bandung: Citra Aditya Bakti.

Sherwood, Robert M. (1990). Intellectual Property and Economic

Development: Westview Special Studies in Science,Technology and Public Agency. SanFransisco: Westview Press Inc.

Sodikin. (2003). Penegakan Hukum Lingkungan: Tinjauan atas Undang-Undang Nomor 23 Tahun 1997. Jakarta: Djambatan.

Soeroso. (2013). Pengantar lImu Hukum. Jakarta: Sinar Grafika.

Susanti, Dyah Ochtorina dan A'an Efendi. (2014). Penelitian Hukum (Legal Research). Jakarta: Sinar Grafika.

Syaifuddin, Muhammad dan Handayani, Sri (2017). Hukum Perlindungan Rekayasa Genetika : Relasi Moral, Hak Kekayaan Intelektual, dan Pelindungan Varietas Tanaman dan Paten di Indonesia. Malang: Setara Press.

Tim Redaksi Kamus Bahasa Indonesia. (2008). Kamus Bahasa Indonesia. Jakarta: Pusat Bahasa Departemen Pendidikan Nasional.

Umam, Khotibul. (2010). Penyelesaian Sengketa di Luar Pengadilan. Yogyakarta: Pustaka Yustisia.

\section{Lain-Lain}

Hanifa, Mila. (2012). Perlindungan Hukum Terhadap Akses dan Pembagian Keuntungan Atas Pemanfaatan Sumber Daya Genetik. Tesis, Universitas Indonesia. Kurniawaty, Yuniar. (2017). Efektivitas 
Alternatif Penyelesaian Sengketa Dalam Sengketa Kekayaan Intelektual (Alternative Dispute Resolution On Intellectual Property Dispute). Jurnal Legislasi Indonesia, Vol. 14 No. 02 - Juni.

Setiono. (2004). Rule of Law (Supremasi Hukum). Surakarta: Program Pascasarjana Universitas Sebelas Maret.

Susanti, Dyah Ochtorina. 2011. Bahan Ajar Mata Kuliah Teori Hukum, disampaikan di Program Pasca Sarjana Ilmu Hukum Universitas Islam Kadiri (UNISKA).

Sitorus, Ade Uswatun. (2015). Hak Cipta dan Perpustakaan. Jurnal Iqra' Vol. 09 No.02, Oktober.

Syahputra, Erwin. (2017). Pengentasan Kemiskinan Melalui Hukum Sebagai Sarana Pemberdayaan CSR (Corporate Social Responsibility) Dalam Kegiatan Pertambangan Emas Di Tapanuli Selatan. Tesis, Universitas Diponegoro.

Tim Peneliti Alternative Disputes Resolution. (2000). Laporan Penelitian Alternative Despute Resolution (Penyelesaian Sengketa Alternatif) dan Court Connected Dispute Resolution (Penyelesaian Sengketa yang Terkait dengan Pengadilan. Jakarta: Proyek Penelitian dan Pengembangan Mahkamah Agung RI.

http://www.probolinggo.org / index.php / beranda / probolinggo kabupaten/krejengan.

http://erepo.unud.ac.id / 9833 / 3 / 0be0ef7 d5a 3081532e17e5236d8ff561. pdf.

http://erepo.unud.ac.id / 9833 / 3 / 0be0e f7d5a 3081532 e 17e5236d8ff561. pdf. 